MTPH Journal, Volume 4, No. 2, September 2020

\title{
FAKTOR-FAKTOR YANG BERHUBUNGAN DENGAN PERILAKU MASYARAKAT DALAM MEMBUANG SAMPAH RUMAH TANGGA KE SUNGAI DI DESA PAMARANGAN KANAN KABUPATEN TABALONG TAHUN 2019
}

\author{
Nia Astina, Akhmad Fauzan, Eddy Rahman \\ ${ }^{1}$ Fakultas Kesehatan Masyarakat, Universitas Islam Kalimantan MAB Banjarmasin \\ Jl. Adhyaksa No. 2, Kayu Tangi, Kota Banjarmasin, Kalimantan Selatan \\ E-mail: niaastina1996@gmail.com
}

\begin{abstract}
Garbage is the solid waste from human activities, garbage has become a national global problem not only locally. Garbage problems arise with an increase in waste dumps by 2-4\% in years. River water pollution due to waste disposal can harm human health, one of which is the increase in diarrheal diseases. The problems examined in this study are factors that relate to people's behaviour in disposing household waste into rivers. This study aims to find out and analyze the relationship between education, knowledge, attitude and availability of facilities with community leaders in disposing household waste into the river. This type of research in quantitative analytical wit a crosssectional approach. Population in this study were all mothers in the Pamarangan Kanan village with a total of 288 households and a sample of 74 respondents, and the sampling technical using proportional random sampling. The research instruments used were questionnaires with interviews method to mothers in the Pamarangan Kanan village. The results of the study indicate that the behaviour of disposing household waste in the Pamarangan Kanan village is behaved badly (60,8\%). The results of analysis there is a relation of knowledge with p-value 0,010, there is a relation of attitude with p-value 0,021, there is a relation of availability of facilities with p-value 0,014, and there is no education relation with p-value 0,634. It's expected that the relevant agencies should be more active in monitoring and providing environmental cleaning service in remote villages and for the community to always carry out waste management activities for the benefit and convenience of the joint.
\end{abstract}

Keywords: Knowledge, Attitude, Availability of Facilities, Education, Garbage Disposal Behavior

\begin{abstract}
ABSTRAK
Sampah merupakan bahan buangan padat dari aktivitas manusia, sampah sudah jadi masalah nasional dan global bukan hanya lokal. Masalah sampah timbul dengan adanya peningkatan timbunan sampah sebesar 2-4\% pertahun. Pencemaran air sungai diakibatkan dari adanya pembuangan sampah yang dapat membawa dampak negatif pada kesehatan, salah satunya seperti meningkatnya penyakit diare. Permasalahan yang dikaji dalam penelitian ini adalah faktor-faktor yang berhubungan dengan perilaku masyarakat dalam membuang sampah rumah tangga ke sungai. Penelitian ini bertujuan untuk mengetahui dan menganalisis hubungan antara pendidikan, pengetahuan, sikap dan ketersediaan sarana dengan perilaku membuang sampah rumah tangga ke sungai. Jenis penelitian ini adalah kuantitatif yang bersifat analitik dengan pendekatan cross sectional. Populasi pada penelitian ini semua ibu di Desa Pamarangan Kanan dengan jumlah 288 rumah tangga dan sampel sebanyak 74
\end{abstract}


responden, teknik pengampilan sampel dengan cara proportional random sampling. Instrumen penelitian yang digunakan adalah kuesioner dengan cara wawancara. Hasil penelitian ini menunjukkan bahwa perilaku membuang sampah rumah tangga di Desa Pamarangan Kanan sebagian besar kurang $(60,8 \%)$. Ada hubungan pengetahuan dengan $p$-value 0,010 , ada hubungan sikap dengan p-value 0,021, ada hubungan ketersediaan sarana dengan p-value 0,014, dan tidak ada hubungan pendidikan dengan $p$-value 0,634. Diharapkan kepada instansi yang terkait agar lebih aktif mengawasi dan memberikan pelayanan kebersihan lingkungan di desa-desa terpencil serta masyarakat agar selalu melakukan kegiatan pengelolaan sampah untuk kepentingan dan kenyamanan bersama.

Kata kunci: Pengetahuan, Sikap, Ketersediaan Sarana, Pendidikan, Perilaku Membuang Sampah

\section{PENDAHULUAN}

Sampah adalah berupa bahan buangan padat dari aktivitas manusia baik dirumah, sekolah, kantor, restoran, pertokoan, tempat umum, pasar dan sebagainya. Besarnya sampah yang dihasilkan dari suatu daerah dipengaruhi oleh tingkat sosial ekonomi masyarakat, semakin tinggi ekonomi yang dimiliki masyarakat maka akan membuat tinggi tingkat konsumsi masyarakat yang akan berdampak pada besarnya timbunan sampah yang di hasilkan ${ }^{1}$.

Laporan World Bank dengan judul "What a Waste: A Global Review of Solid Waste Management", kenaikan jumlah sampah padat sebanyak $70 \%$ sampai tahun 2025 dari 1,3 miliar ton per tahun menjadi 2,2 ton per tahun. Dengan jumlah penduduk sebanyak 237 juta orang, ini menjadikan Indonesia sebagai negara terbanyak ke empat di dunia. Jumlah sampah yang di produksi mencapai 130.000 ton per hari, ini dikarenakan jumlah penduduk yang selalu bertambah. Penduduk Indonesia dengan sanitasi buruk yaitu 72.500 .000 jiwa, dengan 240 kota yang bermasalah dengan pengelolaan sampah ${ }^{2}$. Masyarakat memiliki kewajiban sebagai partisipasi aktif dalam pengelolaan sampah, yaitu kewajiban masyarakat yang dilayani membayar retribusi untuk sumber pendapatan pengelolaan operasional persampahan ${ }^{3}$.

Volume sampah di Kalimantan Selatan hampir 2.100 ton perharinya dan mencapai 766 ribu ton pertahunnya. Dari jumlah itu $14 \%$ nya adalah sampah plastik yang diperkirakan sebesar 295,6 ton perhari atau 107 ribu ton setahun. Jumlah sampah ini dipastikan akan terus meningkat sering bertambahnya jumlah penduduk. Terkait penanganan sampah ini Kalimantan Selatan telah membangun TPA regional untuk menjangkau 5 wilayah yang disebut Banjarbakula meliputi Kota Banjarmasin dan Banjarbaru, juga Kabupaten Barito Kuala, Banjar serta Tanah Laut. TPA Regional Bajar-bakula akan segera dioperasikan pada awal 2019.

Pengelolaan sampah di Kabupaten Tabalong secara bertahap mengupayakan 
adanya pengurangan sampah dengan telah dibangunnya sejak tahun 2014 s/d 2017 sebanyak 5 unit TPS 3R, 15 unit bank sampah dilingkungan masyarakat (permukiman), serta 28 bank sampah di lingkungan sekolah. Namun secara umum sistem pengelolaan sampah di Kabupaten Tabalong belum sepenuhnya mencerminkan sistem pengelolaan yang terintegrasi dan berkelanjutan, dimana fungsi $3 R$ belum sepenuhnya dapat diterapkan, hal ini terlihat bahwa sistem pengolahan sampah di TPA Maburai masih menerapkan open dumping.

Berdasarkan survei pendahuluan yang dilakukan pada bulan April di Desa Pamarangan Kanan peneliti melakukan wawancara terhadap 10 responden yaitu ibu rumah tangga, terdapat 8 dari 10 ibu rumah tangga menyatakan bahwa mereka membuang sampahnya tidak pada tempatnya atau lebih tepatnya membuang sampah di bantaran atau dialiran sungai, hal ini disebabkan oleh berbagai faktor diantaranya yaitu kurangnya pengetahuan tentang membuang sampah yang benar, responden juga menyatakan tidak mempunyai sarana tempat untuk pembuangan sampah yang memadai.

Tujuan pada penelitian ini untuk mengetahui hubungan pendidikan, pengetahuan, sikap, dan ketersediaan sarana dengan perilaku masyarakat dalam membuang sampah rumah tangga ke sungai di Desa Pamarangan Kanan Kabupaten Tabalong Tahun 2019. Penelitian ini dengan demikian agar dapat memberikan masukan kepada masyarakat tentang pentingnya menjaga dan mendukung proses penyehatan lingkungan guna meningkatkan lingkungan yang bersih dan sehat.

\section{METODE PENELITIAN}

Penelitian menggunakan desain Cross Sectional yang bersifat deskriptif analitik dengan penelitian kuantitatif. Populasi dalam penelitian ini adalah semua ibu yang bertempat tinggal di Desa Pamarangan Kanan dengan jumlah rumah tangga. Besar sampel yang menggunakan perhitungan rumus Slovin dan didapatkan hasil sebanyak 74 responden. Pada penelitian ini teknik pengambilan sampel yang digunakan yaitu dengan cara proportional random sampling. Penelitian yang digunakan untuk memenuhi data Pendidikan, Pengetahuan, Sikap, Ketersediaan Sarana dengan perilaku masyarakat dalam membuang sampah rumah tangga ke sungai di Desa Pamarangan Kanan Kabupaten Tabalong Tahun 2019.

\section{HASIL DAN PEMBAHASAN}

Hasil dari pengolahan data akan disajikan dengan analisis univariat dan analisis bivariat.

Tabel 1. Hasil Analisis Univariat

\begin{tabular}{lcc}
\hline \multicolumn{1}{c}{ Variabel Penelitian } & $\mathrm{n}$ & $\%$ \\
\hline Pendidikan & & \\
\hline Tinggi & 37 & 50,0 \\
\hline Rendah & 37 & 50,0 \\
\hline Umur & & \\
\hline $20-30$ & 17 & 23,0 \\
\hline $31-40$ & 25 & 33,8 \\
\hline $41-51$ & 24 & 32,4 \\
\hline$>50$ & 8 & 10,8 \\
\hline
\end{tabular}




\begin{tabular}{lcr}
\hline \multicolumn{1}{c}{ Variabel Penelitian } & $\mathrm{n}$ & $\%$ \\
\hline Status Pekerjaan & & \\
\hline Bekerja & 38 & 51,4 \\
\hline Tidak Bekerja & 36 & 48,6 \\
\hline Perilaku Masyarakat & & \\
\hline Baik & 29 & 39,2 \\
\hline Kurang & 45 & 60,8 \\
\hline Pengetahuan & & \\
\hline Baik & 12 & 16,2 \\
\hline Cukup & 18 & 24,3 \\
\hline Kurang & 44 & 59,5 \\
\hline Sikap & & \\
\hline Positif & 23 & 31,1 \\
\hline Negatif & 51 & 68,9 \\
\hline Ketersediaan Sarana & & \\
\hline Ada & 18 & 24,3 \\
\hline Tidak Ada & 56 & 75,7 \\
\hline Total & 74 & 100,0 \\
\hline
\end{tabular}

\section{Pendidikan}

Pada Tabel 1. menunjukkan distribusi frekuensi pendidikan yang didapatkan dari 74 responden yaitu terdapat responden yang berpendidikan tinggi sebanyak 37 responden (50\%) dan responden yang berpendidikan rendah sebanyak 37 responden (50\%). Orang yang mempunyai pendidikan tinggi akan memberikan pengetahuan yang lebih luas lagi, daripada seseorang yang mempunyai pendidikan lebih rendah dalam halnya tentang pembangunan dan pengelolaan sampah rumah tangga dilihat dari pengetahuan. Konsep pendidikan mengatakan bahwa pendidikan adalah transmisi kebudayaan dari satu ke generasi lainnya untuk meperoleh dan menyampaikan pengetahuan. Pendidikan yang akan berperan untuk mengembangkan kemampuan kearah yang diinginkan dan yang di harapkan, setiap orang mempunyai latar

pendidikan yang berbeda-beda dan tujuannya memperoleh informasi tentang pengetahuan ${ }^{4}$.

\section{Perilaku Masyarakat}

Pada Tabel 1. menunjukkan distribusi frekuensi perilaku masyarakat dalam membuang sampah rumah tangga ke sungai dari 74 responden menunjukkan bahwa responden paling banyak memiliki perilaku yang kurang sebanyak 45 responden $(60,8 \%)$ dibandingkan dengan responden yang memiliki perilaku baik sebanyak 29 responden $(39,2 \%)$. Hal ini disebabkan karena pengetahuan responden yang kurang terhadap pengelolaan sampah yang benar, pendidikan yang menunjang pengetahuan, sikap serta apakah tersedianya sarana tempat pembuangan sampah sehingga memicu seseorang berperilaku yang kurang terhadap penanganan sampah yang dihasilkannya.

Perilaku individu digunakan untuk interaksi dengan lingkungan, mulai dari perilaku yang tidak nampak sampai yang paling nampak, dari yang paling tidak dirasakan sampai yang dirasakan, perilaku yang kurang terhadap kebiasaan membuang sampah sembarangan tidak mengenal tingkatan pendidikan serta status sosial, kurangnya kesadaran betapa pentingnya kebersihan menjadi faktor yang paling dominan selain itu kepekaan masyarakat terhadap lingkungan harus dipertanyakan. Mereka tidak mengetahui bahaya apa saja yang akan terjadi apabila tidak dapat menjaga lingkungan sekitar ${ }^{5}$. 


\section{Pengetahuan}

Pada Tabel 1. menunjukkan distribusi frekuensi pengetahuan dari 74 responden dterdapat 44 responden $(59,5 \%)$ mempunyai pengetahuan kurang, terdapat 18 responden (18,3\%) yang mempunyai pengetahuan cukup, lalu kemudian terdapat 12 responden $(16,2 \%)$ yang mempunyai pengetahuan baik $(16,2 \%)$, hal ini merupakan gambaran bahwa masyarakat kurang menyadari tentang pentingnya pemeliharaan lingkungan dan dampak apa saja yang akan ditimbulkan apabila kebiasaan membuang sampah rumah tangga ke sungai. Beberapa tingkatan khususnya tentang pengetahuan responden juga mempengaruhi perilaku membuang sampah rumah tangga ke sungai, responden yang tidak bisa menjawab pertanyaan yang telah diberikan oleh peneliti yaitu berpengetahuan kurang artinya dengan kurangnya pengetahuan responden tentang pembuangan sampah rumah tangga ke sungai dan aspek yang terkait akan mempengaruhi perilaku membuang sampah rumah tangga ke sungai. Berdasarkan pendekatan perilaku mengenalkan yang disebut cognitive process yaitu proses mental dimana orang mendapatkan, mengorganisasikan dan menggunakan pengetahuannya untuk memberi arti dan makna terhadap ruang yang digunakan. Jadi proses mental seseorang menggunakan pengetahuannya tentang pembuangan sampah rumah tangga sesuai dengan pengetahuan yang dimiliki. Semakin beragam sumber informasi yang didapat seseorang maka akan semakin baik pula pengetahuan tersebut ${ }^{6}$.

\section{Sikap}

Pada Tabel 1 menunjukkan distribusi frekuensi sikap dari 74 responden terdapat 51 responden $(68,9 \%)$ yang mempunyai sikap negatif, lalu kemudian terdapat 23 responden $(32,1 \%)$ yang mempunyai sikap positif, berdasarkan hasil penelitian yang dilakukan oleh peneliti dengan mewawancarai responden, sebagian besar mempunyai sikap yang negatif, yaitu kebanyakan dari mereka yang menyatakan ketidaksetujuannya terhadap pengelolaan sampah dipisah sebelum dibuang, dan juga mereka menyakatan bahwa sampah yang masih bisa di daur ulang lebih baik dibakar saja dari pada mendaur ulang kembali.

\section{Ketersediaan Sarana}

Pada Tabel 1 menunjukkan distribusi frekuensi ketersediaan sarana dari 74 responden terdapat 56 responden $(75,7 \%)$ yang tidak memiliki sarana pembuangan sampah dan terdapat 18 responden $(24,3 \%)$ yang memiliki sarana pembuangan sampah. Berdasarkan hasil penelitian di atas menunjukkan bahwa responden yang tidak memiliki sarana pembuangan sampah lebih banyak yaitu 56 orang responden $(75,7 \%)$. Pada sebagian masyarakat yang mempunyai sarana pembuangan sampah tetapi masih berperilaku kurang yaitu membuang sampah rumah tangga ke sungai berdasarkan observasi yang dilakukan oleh peneliti mereka mengatakan tidak adanya 
tempat pembuangan akhir sampah yang tersedia di desa tersebut dan juga mereka tidak meman- faatkan lahan kosong yang ada untuk pemerosesan akhir sampah sendiri.

Tabel 2. Hasil Analisis Bivariat

\begin{tabular}{|c|c|c|c|c|c|c|c|}
\hline \multirow{3}{*}{ Variabel Penelitian } & \multicolumn{4}{|c|}{$\begin{array}{l}\text { Perilaku Masyarakat Dalam Membuang } \\
\text { Sampah Rumah Tangga Ke Sungai }\end{array}$} & \multirow{2}{*}{\multicolumn{2}{|c|}{ Jumlah }} & \multirow[t]{3}{*}{$p$-value } \\
\hline & \multicolumn{2}{|c|}{ Baik } & \multicolumn{2}{|c|}{ Kurang } & & & \\
\hline & $\mathrm{n}$ & $\%$ & $\mathrm{n}$ & $\%$ & $\mathrm{n}$ & $\%$ & \\
\hline \multicolumn{8}{|l|}{ Pendidikan } \\
\hline Tinggi & 16 & 43,2 & 21 & 56,8 & 37 & 100,0 & \multirow[t]{2}{*}{0,634} \\
\hline Rendah & 13 & 35,1 & 24 & 64,9 & 37 & 100,0 & \\
\hline \multicolumn{8}{|l|}{ Pengetahuan } \\
\hline Baik & 7 & 58,3 & 5 & 41,7 & 12 & 100,0 & \multirow{3}{*}{0,010} \\
\hline Cukup & 11 & 61,1 & 7 & 38,9 & 18 & 100,0 & \\
\hline Kurang & 11 & 25,0 & 33 & 75,0 & 44 & 100,0 & \\
\hline \multicolumn{8}{|l|}{ Sikap } \\
\hline Positif & 14 & 60,9 & 9 & 39,1 & 23 & 100,0 & \multirow[t]{2}{*}{0,021} \\
\hline Negatif & 14 & 9,4 & 36 & 70,6 & 52 & 100,0 & \\
\hline \multicolumn{8}{|l|}{ Ketersediaan Sarana } \\
\hline Ada & 12 & 66,7 & 6 & 33,3 & 18 & 100,0 & \multirow[t]{2}{*}{0,014} \\
\hline Tidak Ada & 17 & 30,4 & 39 & 69,6 & 56 & 100,0 & \\
\hline
\end{tabular}

Hubungan Pendidikan dengan Perilaku Masyarakat dalam Membuang Sampah

\section{Rumah Tangga ke Sungai}

Berdasarkan Tabel 2 bahwa hasil dari penelitian terdapat responden berpendidikan tinggi dan berperilaku kurang sebanyak 21 responden $(56,8 \%)$, sedangkan responden berpendidikan rendah dan berperilaku kurang sebanyak 24 responden (64,9\%). Dari uji statistik Chi Square diperoleh $p$-value $=0,634$, artinya tidak ada hubungan pendidikan dengan perilaku masyarakat dalam membuang sampah rumah tangga ke sungai Desa Pamarangan Kanan Kabupaten Tabalong Tahun 2019.

Penelitian ini sejalan dengan penelitian Novita dkk dari hasil analisis responden memiliki pendidikan tinggi yaitu 54 orang $(66,7 \%)$ sedangkan yang memiliki pendidikan rendah sebanyak 27 orang responden $(33,3 \%)^{7}$. Masyarakat kelurahan Bener lebih banyak memiliki pendidikan yang tinggi. Diperoleh nilai $\mathrm{p}=0,355$ dengan (alpha) $=0,050$ yang berarti dapat dikatakan bahwa tidak ada hubungan antara tingkat pendidikan dengan perilaku membuang sampah, yang berarti pendidikan tidak bermakna secara statistik dan biologi. Pendidikan adalah suatu proses dengan metodemetode tertentu, sehingga orang memperoleh pengetahuan, pemahaman, pengalaman dan cara bertingkah laku yang sesuai dengan kebutuhan. Pendidikan merupakan upaya untuk meningkatkan pengetahuan dan merubah sikap, 
sehingga responden yang memiliki pendidikan tinggi memiliki perilaku yang baik dalam pengelolaan sampahnya. Perilaku membuang sampah sembarangan tidak mengenal tingkat pendidikan maupun status sosial. Keberadaan sampah di kehidupan seharihari tak lepas dari tangan manusia yang membuang sampah sembarangan, mereka menganggap barang yang telah dipakai tidak memiliki kegunaan lagi dan membuang dengan seenaknya sendiri. Kurang kesadaran akan pentingnya kebersihan menjadi faktor yang paling dominan, di samping itu kepekaan masyarakat terhadap lingkungan harus dipertanyakan. Salah satu bentuk perilaku membuang sampah. Pada masyarakat adalah dengan membuang sampah di sungai. Kondisi ini menyebabkan lingkungan di sekitar tepi sungai terlihat sangat kotor akibat tumpukan sampah, lalat beterbangan, banyak tikus dan nyamuk, bahkan menyebarkan aroma yang tidak sedap $^{8}$.

\section{Hubungan Pengetahuan dengan Perilaku} Masyarakat dalam Membuang Sampah Rumah Tangga ke Sungai

Tabel 2 didapatkan hasil yaitu responden pengetahuan baik dan mempunyai perilaku kurang atau membuang sampah rumah tangga ke sungai sebanyak 5 orang $(41,7 \%)$, lalu terdapat responden yang mempunyai pengetahuan cukup dan berperilaku membuang sampah rumah tangga ke sungai sebanyak 7 responden $(38,9 \%)$ sedangkan responden yang mempunyai penge- tahuan kurang dan berperilaku kurang sebanyak 33 responden (75\%). Uji Chi Square didapat $p$ value $=0,010$, ada hubungan pengetahuan dengan perilaku dalam membuang sampah rumah tangga ke sungai Desa Pamarangan Kanan Kabupaten Tabalong Tahun 2019.

Penelitian Ashidiqy berdasarkan hasil penelitian yang didapatkan terdapat 25 orang (40\%) mempunyai pengetahuan baik dan cukup sedangkan 42 orang $(60 \%)$ yang mempunyai pengetahuan yang kurang. Diperoleh nilai $\mathrm{p}=0,001$ dengan $($ alpha $)=0,050^{9}$. Notoatmodjo menyatakan perilaku didasari dengan pengetahuan itu akan lebih baik dibandingkan dengan perilaku yang tidak didasari oleh pengetahuan. Dengan dari individu ataupun kelompok dapat membuat perubahan dengan berperilaku positif ${ }^{4}$.

Diharapkan pengetahuan lebih ditingkatkan khususnya untuk pembuangan dan pengelolaan sampah rumah tangga yang sesuai yaitu dengan memenuhi beberapa syarat yaitu syarat kesehatan, dan peningkatan pengetahuan dapat berupa penyuluhan maupun memberikan informasi yang berhubungan dengan pembuangan dan pengelolaan sampah rumah tangga. Semakin banyak ragam sumber pengetahuan informasi atau penyuluhan yang diperoleh sesorang maka semakin baik pengetahuan orang tersebut $^{6}$. Dengan demikian untuk meningkatkan pengetahuan responden mengenai pembuangan sampah rumah tangga perlu diadakan penyuluhan terhadap masyarakat. 


\section{Hubungan Sikap dengan Perilaku Masyarakat dalam Membuang Sampah Rumah Tangga ke Sungai}

Dari Tabel 2 terdapat responden yang mempunyai sikap positif dan berperilaku kurang atau membuang sampah rumah tangga di sungai yaitu 9 orang $(39,1 \%)$, dan terdapat responden yang mempunyai sikap negatif dan berperilaku kurang dalam membuang sampah ke sungai sebanyak 36 orang (70,6\%). Dari uji statistik Chi Square diperoleh $p$-value $=0,021$, artinya ada hubungan sikap dengan perilaku masyarakat dalam membuang sampah rumah tangga ke sungai di Desa Pamarangan Kanan Kabupaten Tabalong Tahun 2019.

Dalam penelitian ini sesuai dari hasil penelitian Ashidiqy dari hasil didapatkan terdapat 22 orang $(32,8 \%)$ yang bersikap positif dan terdapat 45 orang responden $(67,2 \%)$ yang bersikap negatif. Diperoleh nilai $\mathrm{p}=0,001$ dengan (alpha) $=0,050^{9}$. Hal tersebut menunjukkan bahwa bahwa ada hubungan antara kedua variabel tersebut. Sikap adalah reaksi atau respon tertutup dari seseorang terhadap suatu stimulus atau objek. Ahli psikologi sosial "Newcomb" menyatakan bahwa "sikap itu merupakan kesiapan atau kesediaan untuk bertindak dan bukan merupakan pelaksanaan notif tertentu" ${ }^{\prime 10}$. Sedangkan menurut Breckler dalam Murdhani memandang sikap sebagai kombinasi efektif, perilaku terhadap dirinya sendiri, orang lain, objek atau isu-isu ${ }^{8}$.
Hubungan Ketersediaan Sarana dengan Perilaku Masyarakat dalam Membuang Sampah Rumah Tangga ke Sungai

Hasil dari penelitian terdapat responden yang mempunyai sarana pembuangan sampah dan berperilaku kurang atau membuang sampah ke sungai sebanyak 6 responden $(33,3 \%)$, dan terdapat responden yang mempunyai sarana pembuangan sampah dan berperilaku kurang atau membuang sampah ke sungai sebanyak 39 orang $(69,6 \%)$. Hasil uji statistik chi square diperoleh $p$-value $=0,014$, artinya ada hubungan tersedianya sarana dengan perilaku masyarakat dalam membuang sampah rumah tangga ke sungai di Desa Pamarangan Kanan Kabupaten Tabalong Tahun 2019.

Penelitian ini sesuai dengan penelitian Ashidiqy $^{9}$ berdasarkan hasil penelitian yang didapatkan terdapat 20 orang responden $(29,9 \%)$ yang mempunyai sarana pembuangan sampah dan terdapat 47 orang responden $(70,1 \%)$ yang tidak mempunyai sarana pembuangan sampah. Diperoleh nilai $p=0,001$ dengan $\alpha=0,050$. Ada hubungan antara kedua variabel tersebut.

\section{SIMPULAN DAN SARAN}

\section{Simpulan}

Sesuai dengan hasil dan pembahasan maka dapat disimpulkan bahwa berdasarkan hasil penelitian menunjukan bahwa responden dengan perilaku kurang atau membuang sampah rumah tangga ke sungai yaitu sebanyak 45 responden $(60,8 \%)$. Pendidikan rendah dengan perilaku 
membuang sampah ke sungai yaitu sebanyak 24 orang ke sungai yaitu sebanyak 33 responden (75\%). Sikap negatif dengan perilaku membuang sampah rumah tangga ke sungai yaitu 36 orang (70,6\%). Responden yang tidak mempunyai sarana dengan perilaku membuang sampah rumah tangga ke sungai yaitu sebanyak 39 responden $(69,6 \%)$. Tidak ada hubungan pendidikan dengan perilaku membuang sampah rumah tangga ke sungai di Desa Pamarangan Kanan Tahun 2019 (p-value = 0,634). Ada hubungan antara pengetahuan dengan perilaku membuang sampah rumah tangga ke sungai di Desa Pamarangan Kanan Tahun 2019 (p-value = 0,010). Ada hubungan antara sikap dengan perilaku membuang sampah rumah tangga ke sungai di Desa Pamarangan Kanan Tahun 2019 ( $p$-value $=0,021)$. Ada hubungan antara ketersediaan sarana dengan perilaku membuang sampah rumah tangga ke sungai di Desa Pamarangan Kanan Tahun 2019 (p-value = 0,014).

\section{Saran}

Bagi Pemerintah Kabupaten Tabalong agar lebih meningkatkan koordinasi antar DinasDinas yang terkait seperti Dinas Lingkungan Hidup agar memberikan pelayanan pengangkutan sampah ke desa-desa terpencil atau menyediakan berupa tempat pembuangan sampah sementara untuk masyarakat disana agar mudah dijangkau oleh masyarakat dan prasarana jasa petugas pengangkutan sampah supaya tidak ada masyarakat yang membuang sampah ke sungai. Bagi masyarakat lebih meningkatkan kesadaran dan kepedulian terhadap lingkungan di sekitar tempat tinggal dengan bersama-sama menjaga dan memelihara serta menaati peraturan yang telah ditetapkan, tidak boleh membuang sampah di sungai dan sembarangan kemudian selalu melakukan kegiatan pengelolaan sampah secara baik untuk kepentingan dan kenyamanan bersama. Bagi peneliti selanjutnya diharapkan agar dapat dijadikan sebagai rujukan penelitian dan meneliti variabel-variabel lain terkait perilaku membuang sampah seperti sosial budaya, pendapatan, dukungan keluarga, pelayanan kesehatan dan sebagainya.

\section{REFERENSI}

1. Winardi. Perencanaan Sistem Pengelolaan Sampah Terpadu. Semarang. 2012.

2. Balitbang Kemenkes RI. Riset Kesehatan Dasar; RISKESDAS. Jakarta: Balitbang Kemenkes RI. 2013.

3. Kementerian Pekerja Umum Sekretariat Jendral Cipta Karya. Materi Bidang Sampah I Diseminasi dan Sosialisasi Keteknikan Bidang PLP. Jakarta. 2012.

4. Notoatmodjo, S. Pendidikan Dan Perilaku Kesehatan. Jakarta : Rineka Cipta. 2003.

5. Usman, N. Implementasi dalam Birokrasi Pembangunan, Bandung. 2004.

6. Azwar, A. Sikap Manusia: Teori dan Pengukurannya. Yogyakarta: Pustakan Belajar. 2005.

7. Novita. Pengetahuan, Sikap, Dan Pendidikan Dengan Perilaku Pengelolaan Sampah Di Kelurahan Bener Tegalrejo. Yogyakarta. 2017. 
MTPH Journal, Volume 4, No. 2, September 2020

ISSN: 2549-189X; e-ISSN: 2549-2993

8. Murdhani, A. Faktor-Faktor Yang Berhubungan Dengan Pengelolaan Sampah Rumah Tangga Di Desa Amawang Kiri Muka Kandangan Hulu Sungai Selatan Tahun 2016. 2016.

9. Ashidiqy, M. R. Analisis Faktor-Faktor Yang Berhubungan Dengan Perilaku Masyarakat Dalam Membuang Sampah Rumah Tangga di Sungai Mranggen Tahun 2009. Skripsi. Universitas Negeri Semarang. 2009.

10. Notoatmodjo, S. Kesehatan Masyarakat Ilmu Dan Seni. Jakarta: Rineka Cipta. 2007. 